\title{
Cost/Benefit Analysis of Tea Production in Pakistan
}

\author{
Abdul Latif ${ }^{1}$, Dr. Shehla Amjad ${ }^{2}$, Altaf Hussain ${ }^{3}$, Fayaz Ali Shah ${ }^{4}$, \\ Jawad Hussain $^{5}$ \\ ${ }^{I}$ (Lecturer, Department of Management Sciences, Hazara University, Havelian Campus, Pakistan) \\ ${ }_{2}^{2}$ (Professor, Department of Development Studies, COMSATS Institute of Information Technology Abbotabad) \\ 3,4,5 (PhD Student, Faculty of Management and Human Resource Development, University Technology \\ Malaysia)
}

\begin{abstract}
Tea is common beverage all over the world. It starts production in the fourth year of tea plantation. Its production increases for the first three to four years and reaches the maturity stage of maximum production in the ninth and tenth year. After reaching the maturity stage it is deeply pruned every fifth year to maintain it at desirable height, which is suitable for fresh leaves plucking. Pakistan has long tradition in tea consumption. However, its cultivation started in 1986 at Shinkiari, Hazara Division. Presently, 700 acres of land is under tea plantation. The aim of this research is to identify and evaluate various determinants of production, cost of production and return of tea cultivation in Hazara Division. The study overviews the existing tea production status and estimates its cost and revenue using primary data. To assess financial viability method used is long term benefit-cost analysis. The analysis is based on 25 years and 80 years data. The benefit-cost ratio is calculated for an average grower and the results show that tea is presently showing no profit-no loss situation at farm level in Pakistan. The result is not different if analysis is based on 25 years or 80 years data. Tea growers make an initial investment for 3-4 years without any returns and then wait up to year $28^{\text {th }}$ to $29^{\text {th }}$ to reach breakeven point. Credit providing institutions should take note of this fact and make plans to help tea growers in this period of tea production. Agriculture experts (researchers and extension personnel) should pay attention to the need of reducing the breakeven period through efforts aiming at greater productivity of tea per unit area because presently there is a big difference in actual and potential production of tea in Pakistan at farm level. Agriculture extension personnel should arrange special training to enhance labor productivity in picking fresh leaves per day from an actual average of $20-25 \mathrm{~kg} /$ day to potential average of $35 \mathrm{~kg} / \mathrm{day}$. The government should take step to increase the present purchase price of Rs. $15 / \mathrm{kg}$ of fresh tea leaves to a level acceptable to both the tea farmers and government.
\end{abstract}

Key Words- Costs, Long-Run Scenario, Pakistan, Revenue, Tea Production

\section{Introduction}

Tea (camellia sinensis L) is used as common beverage in almost all over the world. It was originated in China and its regular drinking began there in the sixth century A.D. It spread to Japan in 1000 A.D. and by the middle of seventeenth century, tea invaded Europe. In the mid eighteenth century, the British started tea cultivation for the first time in their colony of India (un-divided) but it was Mr. Robert Fortune, an English botanist who, after studying tea cultivation for four years in China, brought 20,000 plants in 1853 to establish tea gardens in India. Tea plant takes 3 to 4 years before it comes into production. Once established, it remains productive for well over 80 to 100 years (NTRI, 1999).

Pakistan has been a major importer of tea. It imported an annual average 116.63 thousand Tonnes of tea during 1995, which increased to 119.70 thousand Tonnes during 1999 and become 115.97 thousand Tonnes during the year 2004. The value of tea imported increased from an annual average of 191,193.00 thousand dollars during 1995 to 245,296.00 thousand dollars during 1999 and become 190,196.00 thousand dollars during the year 2004 (FAO, 2006).

Pakistan relies almost exclusively on imports to satisfy its internal consumption. Kenya is the dominant supplier of tea to this market, accounting for 66 percent of Pakistan's import requirements in 2003. Despite being the world's largest tea producer and third largest exporter, and having an extensive common border with Pakistan, India only supplies 3 percent of Pakistan's imports. However, a significant quantity is reportedly smuggled into Pakistan from India. Other suppliers include Bangladesh, China (green tea) and Indonesia. Market shares of teas from Kenya, China and India have increased considerably over the last ten years at the expense of Bangladesh and Indonesian tea (FAO, 2005).

Government initiated efforts to promote tea cultivation in the country over last two decades. Chinese tea experts under the technical assistance program of China carried out a soil survey of the prospective tea growing areas of northern hilly tracts of Hazara Division and Central Swat in NWFP in 1982 and then in 1989. A National Tea Research Station (NTRS) was set up in 1986 on 50 acres at Shinkiari. Since then, tea promotion 
efforts are in progress on small scale which would take several years for making significant break through in tea production. Currently, 700 acres has been brought under tea plantation. In addition, two tea processing plants, one in public sector and the other in private sector have been established to provide industrial link. A crash tea program has been launched to accelerate the progress in tea plantation (Hanif, et al. 2004).

This research intends to identify and evaluate various determinants of production, cost of production and returns of tea cultivation in the favorable areas of Hazara division. The findings of the study are expected to be of great importance as it would provide information on major factors responsible for production, cost and net revenue of tea that would lead to take initiative to improve quality and quantity of tea production. Additionally, results and recommendations will help policy makers, extension workers, farmers and other stakeholders to formulate improved strategies for the betterment of the tea cultivation business.

\section{Methodology}

Tea production is a long-term project in which income is generated from year four or five. Costs are high and there is no or little revenue in the initial years. The cost then decreases and income increases during the productive life of tea plant. The purpose of the study was to estimate cost, production and returns of tea cultivation in the tea growing areas of Hazara division. For the intended purpose, the following methodology was developed.

\section{II.I. Analytical Framework}

Careful planning is needed to allocate scarce resources amongst the different farming activities, in a way that the best alternative satisfies the respective requirements. Detailed calculations are necessary for the farmers to determine the capital needed to implement his plans and to forecast its financial results.

It should be kept in mind that tea plantation is a long-term project and generates only income form year four or five from establishment. Measures should thus be taken to maintain a cash flow during that period. The important question is the viability and survival of the project. This question can be answered by making financial analysis of the investment. Since tea plant generates return over a long period of time and early few years involve only cost, while the returns are nil. Keeping in mind such conditions, the present study has been designed to determine returns from tea plantation for the first 25 years and then extending the analysis to 80 years i.e. the productive life of tea plant.

\section{II.II. Universe of study}

Districts Mansehra and Battgram being the main tea producing areas in Pakistan is the universe of this study.

\section{II.III. Sample size}

There are a handsome number of tea growers in the targeted area but due to financial and time constraint it was not possible to select all the tea growers. Therefore, this study was carried out by using purposive sampling technique and selecting only those farmers whose tea production has already been started i.e. the farmers who started tea cultivation in the year 2002 or before.

\section{II.IV. Data collection}

This research was based on primary as well as secondary data. Primary data was collected on cost and returns of tea production from selected growers in the aforementioned district of Hazara division. An interview schedule was designed and used to collect the primary data. Interview schedule was prepared to cover all the relevant information needed for the study. It was pre-tested and modified according to the feedback from the farmers. Farmers were interviewed mainly on their farms and sometimes in their houses.

\section{II.V. Analysis of Data}

Since the tea plant is reported to be productive for many years, therefore cost and returns are concluded using budgeting procedure first and then applied long run analysis approach, namely discounting future streams of expenses and benefits to their present values (Bakhsh, et al. 2006).

We estimated Benefit-Cost $(\mathrm{B} / \mathrm{C})$ ratio using the following formula.

$\mathrm{B} / \mathrm{C}$ Ratio $=\left[\sum\left\{\mathrm{R}_{\mathrm{n}} /(1+\mathrm{i})^{\mathrm{n}}\right\}\right] /\left[\sum\left\{\mathrm{C}_{\mathrm{n}} /(1+\mathrm{i})^{\mathrm{n}}\right\}\right]$

Where $\mathrm{R}$ and $\mathrm{C}$ stand for revenue and costs and (n) and (i) stand for number of years and rate of interest, respectively. The above formula calculates B/C Ratio by dividing sum of discounted revenues generated during the life of production over the sum of discounted costs incurred. For practical manual calculation, the formula (1) can be extended as follows

$$
\sum\left\{\mathrm{R}_{\mathrm{n}} /(1+\mathrm{i})^{\mathrm{n}}\right\}=\left\{\mathrm{R}_{0} /(1+\mathrm{i})^{0}\right\}+\left\{\mathrm{R}_{1} /(1+\mathrm{i})^{1}\right\}+\left\{\mathrm{R}_{2} /(1+\mathrm{i})^{2}\right\} \ldots+\left\{\mathrm{R}_{\mathrm{n}} /(1+\mathrm{i})^{\mathrm{n}}\right\}
$$

$=\left\{\mathrm{C}_{0} /(1+\mathrm{i})^{0}\right\}+\left\{\mathrm{C}_{1} /(1+\mathrm{i})^{1}\right\}+\left\{\mathrm{C}_{2} /(1+\mathrm{i})^{2}\right\} \ldots+\left\{\mathrm{C}_{\mathrm{n}} /(1+\mathrm{i})^{\mathrm{n}}\right\}$

(2) $\sum\left\{\mathrm{C}_{\mathrm{n}} /(1+\mathrm{i})^{\mathrm{n}}\right\}$

Taking interest rate at $(\mathrm{i})=10$ percent the value of denominator $(1+\mathrm{i})^{\mathrm{n}}$ in the equation (2) and (3) is computed as 
follows.

$$
\begin{aligned}
& (1+\mathrm{i}) 0=(1+0.10) 0=1 \\
& (1+\mathrm{i}) 1=(1+0.10) 1=1.10 \\
& (1+\mathrm{i}) 2=(1+0.10) 2=1.21 . \\
& (1+\mathrm{i})^{\mathrm{n}}=(1+0.10)^{\mathrm{n}}=\mathrm{N}
\end{aligned} .
$$

Since prices of Year-4 are used thus the above figures (4) are used for discounting of future values (Hussain, 2006).

For Year- 1 to 3, the figures of cost and revenues are compounded using the following formulas.

$$
\begin{aligned}
& \sum\{\mathrm{Rn}(1+\mathrm{i}) \mathrm{n}\}=\{\mathrm{R} 0(1+\mathrm{i}) 0\}+\{\mathrm{R} 1(1+\mathrm{i}) 1\}+\{\mathrm{R} 2(1+\mathrm{i}) 2\} \ldots+\{\mathrm{Rn}(1+\mathrm{i}) \mathrm{n}\} \\
& \sum\{\mathrm{Cn}(1+\mathrm{i}) \mathrm{n}\}=\{\mathrm{C} 0(1+\mathrm{i}) 0\}+\{\mathrm{C} 1(1+\mathrm{i}) 1\}+\{\mathrm{C} 2(1+\mathrm{i}) 2\} \ldots+\{\mathrm{Cn}(1+\mathrm{i}) \mathrm{n}\}
\end{aligned}
$$

Using the equations (5) and (6), the weights for compounding are calculated. After entering the values calculated for discounting and compounding, $\mathrm{B} / \mathrm{C}$ ratio is computed as already discussed in equation (1). The ratio of the present value of the benefits to the present value of the costs must be greater than one (Watkins and Silicon, 2007).

\section{Results And Disscussion}

According to the information collected from 30 tea growers in District Mansehra and Battgram, tea plant starts production in the fourth year of tea plantation. Its production increases for the first three to four years and reaches the maturity stage of maximum production in the ninth and tenth year. After reaching the maturity stage tea plant is deeply pruned every fifth year to maintain the tea plants at desirable height, which is suitable for fresh leaves plucking. This deep pruning at five years interval also keeps tea plant to give maximum production for many subsequent years.

Data Collected from sampled respondent on input used and various operations involved have been analyzed in term of averages, minimum and maximum ranges and summary of such statistics is provided in Table 1.

\begin{tabular}{|c|c|c|c|c|c|}
\hline Year & Input/Operation & Mean Value & Minimum & Maximum & $\begin{array}{l}\text { Percentage of } \\
\text { Total Labors }\end{array}$ \\
\hline \multirow[t]{4}{*}{$1^{\text {st }}$ Year } & No. Of Plants Sown & 5000 & 5000 & 5000 & \\
\hline & $\begin{array}{l}\text { Land Preparation } \\
\text { Tractor (Hours) }\end{array}$ & 1.5 & 1 & 2 & \\
\hline & $\begin{array}{l}\text { Labor (Days) } \\
\text { For Land Preparation } \\
\text { For fertilizer Application } \\
\text { For Irrigation } \\
\text { For Weeding and pruning } \\
\text { For Picking of Leaves } \\
\text { Total Labor (Days) }\end{array}$ & $\begin{array}{l}10 \\
3 \\
4 \\
5 \\
- \\
22\end{array}$ & $\begin{array}{l}8 \\
2 \\
3 \\
3 \\
-\end{array}$ & $\begin{array}{l}12 \\
3 \\
10 \\
15 \\
-\end{array}$ & $\begin{array}{l}45.45 \\
13.63 \\
18.18 \\
22.73\end{array}$ \\
\hline & $\begin{array}{l}\text { Fertilizer Application } \\
\text { FYM (Trolley) } \\
\text { Mixture of Fertilizer (Bags) }\end{array}$ & 1 & 1 & 1 & \\
\hline \multirow[t]{4}{*}{$\begin{array}{l}2^{\text {nd }} \\
\text { Year }\end{array}$} & No. Of Plants Sown & 1461.25 & 750 & 3400 & \\
\hline & $\begin{array}{l}\text { Land Preparation } \\
\text { Tractor (Hours) }\end{array}$ & - & - & - & \\
\hline & $\begin{array}{l}\text { Labor (Days) } \\
\text { For Land Preparation } \\
\text { For fertilizer Application } \\
\text { For Irrigation } \\
\text { For Weeding and pruning } \\
\text { For Picking of Leaves } \\
\text { Total Labor (Days) } \\
\end{array}$ & $\begin{array}{l}4.39 \\
4 \\
4.48 \\
5.41 \\
- \\
\mathbf{1 8 . 2 8}\end{array}$ & $\begin{array}{l}1.75 \\
3 \\
3 \\
3.5 \\
-\end{array}$ & $\begin{array}{l}8 \\
5 \\
10 \\
6 \\
-\end{array}$ & $\begin{array}{l}24.01 \\
21.88 \\
24.51 \\
29.60\end{array}$ \\
\hline & $\begin{array}{l}\text { Fertilizer Application } \\
\text { FYM (Trolley) }\end{array}$ & & & & \\
\hline
\end{tabular}

III.I. The First Year: According to the data in Table 1, on average, 5000 plants were sown per acre in the tea garden during the first year. Tea growers used tractor for preparation of land for tea plantation. On average, 1.5 hours of tractor were used per acre for land preparation. A total of 22 labor days were used for various operations, namely land

Table 1: Inputs used/ Operation involved in Tea Production (per Acre) 
Cost/Benefit Analysis Of Tea Production In

\begin{tabular}{|c|c|c|c|c|c|}
\hline & Mixture of Fertilizer (Bags) & 3 & 3 & $\overline{3}$ & \\
\hline \multirow[t]{4}{*}{$\begin{array}{l}3^{\text {rd }} \\
\text { Year }\end{array}$} & No. Of Plants Sown & 976.37 & 425 & 2050 & \\
\hline & $\begin{array}{l}\text { Land Preparation } \\
\text { Tractor (Hours) }\end{array}$ & & & & \\
\hline & $\begin{array}{l}\text { Labor (Days) } \\
\text { For Land Preparation } \\
\text { For fertilizer Application } \\
\text { For Irrigation } \\
\text { For Weeding and pruning } \\
\text { For Picking of Leaves } \\
\text { Total Labor (Days) } \\
\end{array}$ & $\begin{array}{l}2.90 \\
4.01 \\
4.42 \\
5.85 \\
- \\
\mathbf{1 7 . 1 7} \\
\end{array}$ & $\begin{array}{l}1 \\
3 \\
3 \\
4 \\
-\end{array}$ & $\begin{array}{l}6 \\
5 \\
8 \\
6 \\
-\end{array}$ & $\begin{array}{l}16.89 \\
23.35 \\
25.74 \\
34.07\end{array}$ \\
\hline & $\begin{array}{l}\text { Fertilizer Application } \\
\text { FYM (Trolley) } \\
\text { Mixture of Fertilizer (Bags) }\end{array}$ & 3 & 3 & 3 & \\
\hline \multirow{4}{*}{$\begin{array}{l}4^{\text {th }} \\
\text { Year }\end{array}$} & No. Of Plants Sown & 556.83 & 300 & 1000 & \\
\hline & $\begin{array}{l}\text { Land Preparation } \\
\text { Tractor (Hours) }\end{array}$ & & & & \\
\hline & $\begin{array}{l}\text { Labor (Days) } \\
\text { For Land Preparation } \\
\text { For fertilizer Application } \\
\text { For Irrigation } \\
\text { For Weeding and pruning } \\
\text { For Picking of Leaves } \\
\text { Total Labor (Days) } \\
\end{array}$ & $\begin{array}{l}2.10 \\
4 \\
4.41 \\
5.67 \\
16.75 \\
\mathbf{3 2 . 9 3} \\
\end{array}$ & $\begin{array}{l}1 \\
3 \\
3 \\
4 \\
12\end{array}$ & $\begin{array}{l}3 \\
5 \\
8 \\
6 \\
24\end{array}$ & $\begin{array}{l}6.38 \\
12.15 \\
13.39 \\
17.22 \\
50.86\end{array}$ \\
\hline & $\begin{array}{l}\text { Fertilizer Application } \\
\text { FYM (Trolley) } \\
\text { Mixture of Fertilizer (Bags) }\end{array}$ & 3 & 3 & 36 & \\
\hline
\end{tabular}

Source: Survey

preparation (45.45 percent), fertilizer application (13.63 percent), irrigation (18.18 percent), weeding and pruning (22.73 percent). No chemical fertilizer (Urea or DAP) was used during the first year; only, 1 trolley of FYM per acre was mixed with soil during land preparation.

III.III. The Second and Third Year: During the second and third year, on average, 1461 and 976 plants were sown per acre respectively to replace the plant effected as a result of mortality. The plants sown ranged between 750 to 3400 in the second year and 425 to 2050 during the third year of tea plantation. The range varies because of difference in the mortality ratio of individual tea gardens.

On average, 18.28 labor days and 17.17 labor days per acre were used during the second and third years, respectively. The labor days decreased just because of lesser replacement of tea plants in the third year. From $2^{\text {nd }}$ year onward, fertilizer comprising a mixture of Ammonium Sulphate, Diammonium Phosphate and Sulphate of Potash is prepared in a ratio of $5: 2: 2$, respectively. Three bags of mixture are applied per acre to the tea garden.

III.IV. The Fourth Year: During the fourth year, on average, 557 plants were sown to replace the plants affected due to mortality. It showed a decreasing trend in plant replaced from $2^{\text {nd }}$ year to $4^{\text {th }}$ year. During the fourth year, on the average, 32.93 labor days were used for different activities. The number of labor days used increased substantially because some production of green tea leaves start from $4^{\text {th }}$ year and labors are required for picking of these fresh tea leaves (51 percent of the total labors are used for picking of fresh leaves). On the average, one labor can pick $25 \mathrm{~kg}$ of fresh leaves per day from the tea garden. Out of the total 32.93 labor days used in the $4^{\text {th }}$ year, 16.75 labor days were used only for picking of fresh leaves and the rest of labor days were used for other activities in the fourth year. Fertilizer is applied in the same ratio as were used in the second and third year of tea plantation. 
III.IV. Cost of Tea Production

Table 2 provides average costs incurred on account of the aforementioned inputs used and operations involved during the $1^{\text {st }}$ to $4^{\text {th }}$ year of tea production.

Table 2: Cost of Tea Production (per Acre)

\begin{tabular}{|c|c|c|c|c|c|}
\hline Years & Particulars & Quantity & Price/unit (Rs.) & Cost (Rs.) & $\begin{array}{l}\text { Percentage } \\
\text { of Total Cost }\end{array}$ \\
\hline \multirow{7}{*}{$1^{\text {st }}$} & No. Of Plants Sown & 5000 & 5 & 25000 & 63.24 \\
\hline & $\begin{array}{l}\text { Land Preparation } \\
\text { Tractor (Hours) }\end{array}$ & 1.5 & 380 & 570 & 1.44 \\
\hline & $\begin{array}{l}\text { Labor (Days) } \\
\text { For Land Preparation } \\
\text { For fertilizer Application } \\
\text { For Irrigation Application } \\
\text { For Weeding and pruning } \\
\text { For Picking of Leaves } \\
\text { Total Labor (Days) }\end{array}$ & $\begin{array}{l}10 \\
3 \\
4 \\
5 \\
- \\
22\end{array}$ & $\begin{array}{l}128 \\
128 \\
128 \\
128 \\
128 \\
128\end{array}$ & $\begin{array}{l}1280 \\
384 \\
512 \\
640 \\
- \\
2816\end{array}$ & 7.12 \\
\hline & For Irrigation & & & 460 & 1.16 \\
\hline & $\begin{array}{l}\text { Fertilizer Application } \\
\text { FYM (Trolley) } \\
\text { Mixture of Fertilizer } \\
\text { (Bags) }\end{array}$ & 1 & 419 & 419 & 1.06 \\
\hline & Land Rent (Acre) & 1 & 10267 & 10267 & 25.97 \\
\hline & Total Cost (1 ${ }^{\text {st }}$ Year $)$ & & & 39600.77 & \\
\hline \multirow{7}{*}{$\begin{array}{l}2^{\text {nd }} \\
\text { Year }\end{array}$} & No. Of Plants Sown & 1461.25 & 5 & 7306.25 & 31.40 \\
\hline & $\begin{array}{l}\text { Land Preparation } \\
\text { Tractor (Hours) }\end{array}$ & & & & \\
\hline & $\begin{array}{l}\text { Labor (Days) } \\
\text { For Land Preparation } \\
\text { For fertilizer Application } \\
\text { For Irrigation Application } \\
\text { For Weeding and pruning } \\
\text { For Picking of Leaves } \\
\text { Total Labor (Days) }\end{array}$ & $\begin{array}{l}4.39 \\
4 \\
4.48 \\
5.41 \\
- \\
\mathbf{1 8 . 2 8}\end{array}$ & $\begin{array}{l}128 \\
128 \\
128 \\
128 \\
128 \\
128\end{array}$ & $\begin{array}{l}561.92 \\
512 \\
573.44 \\
692.48 \\
- \\
2339.84\end{array}$ & 10.06 \\
\hline & For Irrigation & & & 460 & 1.98 \\
\hline & $\begin{array}{l}\text { Fertilizer Application } \\
\text { FYM (Trolley) } \\
\text { Mixture of Fertilizer } \\
\text { (Bags) }\end{array}$ & 3 & 964.33 & 2893 & 12.43 \\
\hline & Land Rent (Acre) & 1 & 10267 & 10267 & 44.13 \\
\hline & Total Cost (2nd Year) & & & 23274.51 & \\
\hline \multirow[t]{4}{*}{$\begin{array}{l}3^{\text {rd }} \\
\text { Year }\end{array}$} & No. Of Plants Sown & 976.37 & 5 & 4881.85 & 23.58 \\
\hline & $\begin{array}{l}\text { Land Preparation } \\
\text { Tractor (Hours) }\end{array}$ & & & & \\
\hline & $\begin{array}{l}\text { Labor (Days) } \\
\text { For Land Preparation } \\
\text { For fertilizer Application } \\
\text { For Irrigation Application } \\
\text { For Weeding and pruning } \\
\text { For Picking of Leaves } \\
\text { Total Labor (Days) }\end{array}$ & $\begin{array}{l}2.90 \\
4.01 \\
4.42 \\
5.85 \\
- \\
\mathbf{1 7 . 1 7}\end{array}$ & $\begin{array}{l}128 \\
128 \\
128 \\
128 \\
128 \\
128\end{array}$ & $\begin{array}{l}371.2 \\
513.28 \\
565.76 \\
748.8 \\
- \\
2199.04\end{array}$ & 10.62 \\
\hline & For Irrigation & & & 460 & 2.22 \\
\hline
\end{tabular}


Cost/Benefit Analysis Of Tea Production In Pakistan

\begin{tabular}{|c|c|c|c|c|c|}
\hline & $\begin{array}{l}\text { Fertilizer Application } \\
\text { FYM (Trolley) } \\
\text { Mixture of Fertilizer } \\
\text { (Bags) }\end{array}$ & 3 & 964.33 & 2893 & 13.98 \\
\hline & Land Rent (Acre) & 1 & 10267 & 10267 & 49.60 \\
\hline & Total Cost (3rd Year) & & & 20709.36 & \\
\hline \multirow[t]{7}{*}{$\begin{array}{l}4^{\text {th }} \\
\text { Year }\end{array}$} & No. Of Plants Sown & 556.83 & 5 & 2784.15 & 13.50 \\
\hline & $\begin{array}{l}\text { Land Preparation } \\
\text { Tractor (Hours) } \\
\end{array}$ & & & & \\
\hline & $\begin{array}{l}\text { Labor (Days) } \\
\text { For Land Preparation } \\
\text { For fertilizer Application } \\
\text { For Irrigation Application } \\
\text { For Weeding and pruning } \\
\text { For Picking of Leaves } \\
\text { Total Labor (Days) }\end{array}$ & $\begin{array}{l}2.10 \\
4 \\
4.41 \\
5.67 \\
16.75 \\
\mathbf{3 2 . 9 3} \\
\end{array}$ & $\begin{array}{l}128 \\
128 \\
128 \\
128 \\
128 \\
128\end{array}$ & $\begin{array}{l}268.8 \\
512 \\
564.48 \\
725.76 \\
2144 \\
4215.04 \\
\end{array}$ & 20.44 \\
\hline & For Irrigation & & & 460 & 2.23 \\
\hline & $\begin{array}{l}\text { Fertilizer Application } \\
\text { FYM (Trolley) } \\
\text { Mixture of Fertilizer } \\
\text { (Bags) }\end{array}$ & 3 & 964.33 & 2893 & 14.03 \\
\hline & Land Rent (Acre) & 1 & 10267 & 10267 & 49.79 \\
\hline & Total Cost (4th Year) & & & 20625.69 & \\
\hline
\end{tabular}

Source: Survey

It appears that on the average, Rs. 39600.77, Rs. 23274.51, Rs. 20709.36 and Rs. 20625.69 per acre were spent during the $1^{\text {st }}-4^{\text {th }}$ years of tea plantation.

In the $1^{\text {st }}$ year, plants sown accounted for highest share (63.24 percent) in the total cost of Rs. 39600.77 per acre, followed by rent of land (25.97 percent), labor days (7.12 percent), land preparation (1.44 percent), irrigation (1.16 percent) and fertilizer application (1.06 percent).

In the second and third year, rent of land accounted for highest cost i.e. 44.13 percent and 49.60 percent, followed by cost on plant sown that accounted 31.40 percent and 23.58 percent, fertilizer accounted for 12.43 percent and 13.98 percent, labor days accounted for 10.06 percent and 10.62 percent and irrigation accounted for 1.98 percent and 2.22 percent of the total costs (Rs. 23274.51 and Rs. 20709.36 per acre), respectively. In the fourth year, land rent, labor days, fertilizer application, number of plant sown and irrigation accounted for 49.79 percent, 20.44 percent, 14.03 percent, 13.50 percent and 2.23 percent of the total cost (Rs. 20625.69) per acre respectively.

\section{III.V. Production, Costs and Revenues: the Long-Run Scenario}

\section{III.V.I. Cost and Revenue of Tea}

Once the tea plant starts production from fourth year it remains productive for over 80 years. For first part of analysis data was collected on estimates of cost for 25 years. It is worth noting that data were collected from growers for the actual expenses incurred during the $1^{\text {st }}-4^{\text {th }}$ years and they were asked to give the estimates for the level of the use of various inputs and operations in the subsequent years. After collecting the data from growers on their estimates for use of inputs/operations for future years, the costs were estimated using the present prices (for $4^{\text {th }}$ year; 2006) for future period. Similarly data were collected from respondent growers on their revenues estimates for 25 years.

The indices of cost and revenues estimates for the Year-1 to Year-25 were also worked out and are given in Table 3. The indices of costs show that, compared to Year-1, costs in the subsequent years are relatively lower because of no expense on preparation of land. The cost on nursery plants also decreases and from $4^{\text {th }}$ year onward there is no expense on nursery plants. The cost slightly increases from Year- 5 to Year- 10 mainly due to increase in labor required for pruning and maintenance, picking of fresh leaves and use of fertilizer. The decrease in cost during Year-11 is mainly because of lower number of labor required for picking of fresh leaves as the production of fresh leaves decrease due to deep pruning of tea plant in the Year-10. Then the cost indices show the same trend throughout the subsequent years.

Tea production and revenues are shown in Table 3. Revenue starts from Year-4, increases up to year-15 and then remains constant throughout the subsequent years of tea plantation. The revenue decreases after every 
Cost/Benefit Analysis Of Tea Production In Pakistan

five-year interval is just because of the deep pruning of tea plant after every five years to keep tea plant at desirable height suitable for picking of fresh tea leaves.

Table 3: Cost and Revenue of Tea for 25 Years (Per Acre)

\begin{tabular}{|l|r|r|r|r|r|r|}
\hline Years & Total Cost (Rs.) & Cost Indices & $\begin{array}{l}\text { Total } \\
\text { Production } \\
\text { Kg) }\end{array}$ & \multicolumn{1}{l|}{$\begin{array}{l}\text { Production } \\
\text { Indices }\end{array}$} & $\begin{array}{l}\text { Total } \\
\text { Revenue } \\
\text { (Rs.) }\end{array}$ & $\begin{array}{l}\text { Revenue } \\
\text { Indices }\end{array}$ \\
\hline Year 1 & 39600.77 & 100.00 & 0.00 & & 0.00 & \\
\hline Year 2 & 23274.51 & 58.77 & 0.00 & & 0.00 & \\
\hline Year 3 & 20709.36 & 52.30 & 0.00 & & 0.00 & \\
\hline Year 4 & 20625.69 & 52.08 & 419.00 & 100.00 & 6285.00 & 100.00 \\
\hline Year 5 & 18395.97 & 46.45 & 593.58 & 141.67 & 8903.75 & 141.67 \\
\hline Year 6 & 19195.60 & 48.47 & 768.17 & 183.33 & 11522.50 & 183.33 \\
\hline Year 7 & 18955.60 & 47.87 & 768.17 & 183.33 & 11522.50 & 183.33 \\
\hline Year 8 & 20563.55 & 51.93 & 1082.42 & 258.33 & 16236.25 & 258.33 \\
\hline Year 9 & 21635.52 & 54.63 & 1291.92 & 308.33 & 19378.75 & 308.33 \\
\hline Year 10 & 21814.18 & 55.09 & 1326.83 & 316.67 & 19902.50 & 316.67 \\
\hline Year 11 & 18716.03 & 47.26 & 593.58 & 141.67 & 8903.75 & 141.67 \\
\hline Year 12 & 21635.52 & 54.63 & 1291.92 & 308.33 & 19378.75 & 308.33 \\
\hline Year 13 & 21635.52 & 54.63 & 1291.92 & 308.33 & 19378.75 & 308.33 \\
\hline Year 14 & 21814.18 & 55.09 & 1326.83 & 316.67 & 19902.50 & 316.67 \\
\hline Year 15 & 21814.18 & 55.09 & 1326.83 & 316.67 & 19902.50 & 316.67 \\
\hline Year 16 & 18716.03 & 47.26 & 593.58 & 141.67 & 8903.75 & 141.67 \\
\hline Year 17 & 21814.18 & 55.09 & 1326.83 & 316.67 & 19902.50 & 316.67 \\
\hline Year 18 & 21814.18 & 55.09 & 1326.83 & 316.67 & 19902.50 & 316.67 \\
\hline Year 19 & 21814.18 & 55.09 & 1326.83 & 316.67 & 19902.50 & 316.67 \\
\hline Year 20 & 21814.18 & 55.09 & 1326.83 & 316.67 & 19902.50 & 316.67 \\
\hline Year 21 & 18716.03 & 47.26 & 593.58 & 141.67 & 8903.75 & 141.67 \\
\hline Year 22 & 21814.18 & 55.09 & 1326.83 & 316.67 & 19902.50 & 316.67 \\
\hline Year 23 & 21814.18 & 55.09 & 1326.83 & 316.67 & 19902.50 & 316.67 \\
\hline Year 24 & 21814.18 & 55.09 & 1326.83 & 316.67 & 19902.50 & 316.67 \\
\hline Year 25 & 21814.18 & 55.09 & 1326.83 & 316.67 & 19902.50 & 316.67 \\
\hline $\begin{array}{l}\text { G. Total } \\
\text { (25 Years) }\end{array}$ & $\mathbf{5 4 2 3 3 1 . 7 2}$ & & & & $\mathbf{3 5 8 2 4 5 . 0 0}$ & \\
\hline & & & & & & \\
\hline
\end{tabular}

\section{III.VI. Benefit-Cost Ratio}

The Costs and Revenues discussed earlier are reproduced in Column 2 and 3 of Table 4. Column 4 works out net revenue over 25 years of tea plantation. This is a crude way of estimating net revenues when production is carried out over number of years. For a long run analysis, the cost and revenues are discounted and Benefit-Cost $(B / C)$ Ratio is estimated using the following formula.

$\mathrm{B} / \mathrm{C}$ Ratio $=\sum\left\{\mathrm{R}_{\mathrm{n}} /(1+\mathrm{i})^{\mathrm{n}}\right\} / \sum\left\{\mathrm{C}_{\mathrm{n}} /(1+\mathrm{i})^{\mathrm{n}}\right\}$

Table 4: Discounted Cost and Revenue of Tea production (per acre)

\begin{tabular}{|c|c|c|c|c|c|c|c|}
\hline \multirow[b]{2}{*}{ Years } & \multicolumn{3}{|c|}{$\begin{array}{l}\text { Values in } 2006 \text { Prices } \\
\text { (Of 4th Year) }\end{array}$} & \multicolumn{2}{|c|}{ Present Values } & \multirow{2}{*}{\begin{tabular}{|c|} 
Present Value \\
Revenues \\
(Rs.)
\end{tabular}} & \multirow{2}{*}{$\begin{array}{c}\begin{array}{c}\text { Present } \\
\text { Value }\end{array} \\
\text { Net } \\
\text { Revenues }\end{array}$} \\
\hline & $\begin{array}{l}\text { Costs } \\
\text { (Rs.) }\end{array}$ & \begin{tabular}{c|}
$\begin{array}{c}\text { Revenues } \\
\text { (Rs.) }\end{array}$ \\
\end{tabular} & $\begin{array}{c}\text { Net } \\
\text { Revenues }\end{array}$ & \begin{tabular}{l|l} 
Weight for \\
Discounting
\end{tabular} & $\begin{array}{l}\text { Costs } \\
\text { (Rs.) }\end{array}$ & & \\
\hline Year-1 & 39600.77 & 0.00 & -39600.77 & 1.331 & 52708.62 & $\begin{array}{r}0.00 \\
\end{array}$ & -52708.62 \\
\hline Year-2 & 23274.51 & 0.00 & -23274.51 & 1.21 & 28162.16 & 0.00 & -28162.157 \\
\hline Year-3 & 20709.36 & 0.00 & -20709.36 & 1.10 & 22780.3 & 0.00 & -22780.296 \\
\hline Year-4 & 20625.69 & 6285.00 & -14340.69 & 1.00 & 20625.69 & 6285.00 & -14340.693 \\
\hline Year-5 & 18395.97 & 8903.75 & -9492.22 & 1.10 & 16723.61 & 8094.3182 & -8629.287 \\
\hline Year-6 & 19195.60 & 11522.50 & -7673.10 & 1.21 & 15864.14 & 9522.7273 & -6341.409 \\
\hline Year-7 & 18955.60 & 11522.50 & -7433.10 & 1.331 & 14241.63 & 8657.0248 & -5584.601 \\
\hline Year-8 & 20563.55 & 16236.25 & -4327.30 & 1.4641 & 14045.18 & 11089.577 & -2955.607 \\
\hline Year-9 & 21635.52 & 19378.75 & -2256.77 & 1.61051 & 13433.96 & 12032.679 & -1401.277 \\
\hline Year-10 & 21814.18 & 19902.50 & -1911.68 & 1.77156 & 12313.54 & 11234.442 & -1079.095 \\
\hline Year-11 & 18716.03 & 8903.75 & -9812.28 & 1.948717 & 9604.284 & 4569.0316 & -5035.252 \\
\hline Year-12 & 21635.52 & 19378.75 & -2256.77 & 2.143589 & 10093.13 & 9040.3299 & -1052.800 \\
\hline Year-13 & 21635.52 & 19378.75 & -2256.77 & 2.35795 & 9175.573 & 8218.4817 & -957.091 \\
\hline
\end{tabular}


Cost/Benefit Analysis Of Tea Production In Pakistan

\begin{tabular}{|l|r|r|r|r|r|r|r|}
\hline Year-14 & 21814.18 & 19902.50 & -1911.68 & 2.59374 & 8410.312 & 7673.2753 & -737.036 \\
\hline Year-15 & 21814.18 & 19902.50 & -1911.68 & 2.85312 & 7645.738 & 6975.7048 & -670.033 \\
\hline Year-16 & 18716.03 & 8903.75 & -9812.28 & 3.13843 & 5963.505 & 2837.0091 & -3126.496 \\
\hline Year-17 & 21814.18 & 19902.50 & -1911.68 & 3.45227 & 6318.792 & 5765.0453 & -553.746 \\
\hline Year-18 & 21814.18 & 19902.50 & -1911.68 & 3.79750 & 5744.356 & 5240.9503 & -503.406 \\
\hline Year-19 & 21814.18 & 19902.50 & -1911.68 & 4.17725 & 5222.142 & 4764.5003 & -457.642 \\
\hline Year-20 & 21814.18 & 19902.50 & -1911.68 & 4.59497 & 4747.402 & 4331.3639 & -416.038 \\
\hline Year-21 & 18716.03 & 8903.75 & -9812.28 & 5.05447 & 3702.867 & 1761.5595 & -1941.308 \\
\hline Year-22 & 21814.18 & 19902.50 & -1911.68 & 5.55992 & 3923.472 & 3579.6396 & -343.833 \\
\hline Year-23 & 21814.18 & 19902.50 & -1911.68 & 6.11591 & 3566.793 & 3254.2178 & -312.575 \\
\hline Year-24 & 21814.18 & 19902.50 & -1911.68 & 6.72750 & 3242.539 & 2958.3798 & -284.159 \\
\hline Year-25 & 21814.18 & 19902.50 & -1911.68 & 7.40025 & 2947.763 & 2689.4362 & -258.327 \\
\hline & & & & & & & \\
\end{tabular}

Where $\mathrm{R}$ and $\mathrm{C}$ stand for revenue and costs and (n) and (i) stand for number of years and rate of interest, respectively. The above formula calculates B/C Ratio by dividing sum of discounted revenues generated during the life of production over the sum of discounted costs incurred.

The values of denominators calculated are included in the $5^{\text {th }}$ column of Table 4 for the Year- 4 to Year-25; it starts from Year-4 because all cost and revenues are valued in Year-4 prices. For the earlier 3 years (Year-1 to Year-3), compounding method is used instead of discounting.

Using the compounded and discounted figures of cost and revenues of Table 4, we can now compute B/C Ratio as follows.

B/C Ratio (25 Years) $=140574.69 / 301207.5=0.467$

This B/C Ratio for 25 years shows that tea is not profitable at farm level in Pakistan that can also be analyzed from the negative values of net revenues in the last column of Table 4 . The farmers are still engaged in tea production technology because of the subsidy provided by government in the form of cost on nursery plant, fertilizers and labors used for picking of fresh leaves. Table 4 is recalculated by incorporating the values of subsidy, which the farmers are getting and the details of costs and revenues after subsidy are given in Table 5 . Using the compounded and discounted figures of costs and revenues by adding subsidy the $\mathrm{B} / \mathrm{C}$ ratio is again calculated as follows.

Table 5: Discounted Costs and Revenues of Tea Production after Adding Subsidy (Per Acre)

\begin{tabular}{|c|c|c|c|c|c|c|}
\hline \multirow[b]{2}{*}{ Years } & \multicolumn{3}{|c|}{$\begin{array}{c}\text { Values in } 2006 \text { Prices } \\
\text { (Of 4th Year) }\end{array}$} & \multicolumn{2}{|l|}{ Present Values } & \multirow{2}{*}{\begin{tabular}{|l} 
Present Value \\
Total Revenue \\
After Subsidy \\
\end{tabular}} \\
\hline & $\begin{array}{l}\text { Total } \\
\text { Cost } \\
\end{array}$ & $\begin{array}{l}\text { Total } \\
\text { Subsidy }\end{array}$ & $\begin{array}{l}\text { Total Revenue } \\
\text { After Subsidy }\end{array}$ & 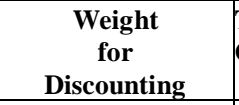 & $\begin{array}{l}\text { Total } \\
\text { Cost }\end{array}$ & \\
\hline Year 1 & 39600.77 & 25419.33 & 25419.33 & 1.331 & 52708.62 & 33833.13 \\
\hline Year 2 & 23274.51 & 10199.24 & 10199.24 & 1.21 & 28162.16 & 12341.08 \\
\hline Year 3 & 20709.36 & 7774.83 & 7774.83 & 1.10 & 22780.30 & 8552.31 \\
\hline Year 4 & 20625.69 & 7819.49 & 14104.49 & 1.00 & 20625.69 & 14104.49 \\
\hline Year 5 & 18395.97 & 5930.23 & 14833.98 & 1.10 & 16723.61 & 13485.44 \\
\hline Year 6 & 19195.60 & 6823.54 & 18346.04 & 1.21 & 15864.13 & 15162.02 \\
\hline Year 7 & 18955.60 & 6823.54 & 18346.04 & 1.331 & 14241.62 & 13783.65 \\
\hline Year 8 & 20563.55 & 8431.49 & 24667.74 & 1.4641 & 14045.18 & 16848.40 \\
\hline Year 9 & 21635.52 & 9503.45 & 28882.20 & 1.61051 & 13433.96 & 17933.57 \\
\hline Year 10 & 21814.18 & 9682.12 & 29584.62 & 1.77156 & 12313.54 & 16699.76 \\
\hline Year 11 & 18716.03 & 5930.23 & 14833.98 & 1.948717 & 9604.28 & 7612.18 \\
\hline Year 12 & 21635.52 & 9503.45 & 28882.20 & 2.143589 & 10093.13 & 13473.76 \\
\hline Year 13 & 21635.52 & 9503.45 & 28882.20 & 2.35795 & 9175.56 & 12248.86 \\
\hline Year 14 & 21814.18 & 9682.12 & 29584.62 & 2.59374 & 8410.32 & 11406.16 \\
\hline Year 15 & 21814.18 & 9682.12 & 29584.62 & 2.85312 & 7645.73 & 10369.22 \\
\hline Year 16 & 18716.03 & 5930.23 & 14833.98 & 3.13843 & 5963.50 & 4726.56 \\
\hline Year 17 & 21814.18 & 9682.12 & 29584.62 & 3.45227 & 6318.79 & 8569.61 \\
\hline Year 18 & 21814.18 & 9682.12 & 29584.62 & 3.79750 & 5744.35 & 7790.55 \\
\hline Year 19 & 21814.18 & 9682.12 & 29584.62 & 4.17725 & 5222.14 & 7082.32 \\
\hline Year 20 & 21814.18 & 9682.12 & 29584.62 & 4.59497 & 4747.40 & 6438.48 \\
\hline Year 21 & 18716.03 & 5930.23 & 14833.98 & 5.05447 & 3702.87 & 2934.82 \\
\hline Year 22 & 21814.18 & 9682.12 & 29584.62 & 5.55992 & 3923.47 & 5321.05 \\
\hline Year 23 & 21814.18 & 9682.12 & 29584.62 & 6.11591 & 3566.79 & 4837.32 \\
\hline Year 24 & 21814.18 & 9682.12 & 29584.62 & 6.72750 & 3242.54 & 4397.57 \\
\hline Year 25 & 21814.18 & 9682.12 & 29584.62 & 7.40025 & 2947.76 & 3997.79 \\
\hline Total & 542331.72 & 232026.02 & $\mathbf{5 9 0 2 7 1 . 0 2}$ & & 301207.46 & 273950.09 \\
\hline
\end{tabular}

B/C Ratio (25 Years) $=273950.09 / 301207.5=0.91 \quad$ ( with subsidy) 
This B/C Ratio of 0.91 , which is approximately equal to 1 for 25 years tea plantation, it shows that tea is presently showing no profit no loss situation at farm level in Pakistan.

\section{III.VII. Benefit-Cost Ratio: Tea Life Cycle}

First part of analysis is now extended to 80 years being the possible productive life of tea plant, the estimate of costs and revenues for life cycle of tea plant. The sum of cost and revenue for every ten years from Year-1 to Year80 are calculated, which are given in Table 6. The Benefit-Cost Ratio is then calculated as follow using the same procedure already discussed in detail in the previous section.

Table 6: Discounted Cost and Revenue of Tea Production (Sum of Every Ten Years)

\begin{tabular}{|l|r|r|r|r|}
\hline & \multicolumn{1}{c|}{ (Per Acre) } \\
\hline Year & \multicolumn{1}{l|}{ Costs } & \multicolumn{1}{l|}{ Revenues } & \multicolumn{1}{l|}{ Discounted Costs } & $\begin{array}{l}\text { Discounted } \\
\text { Revenues }\end{array}$ \\
\hline Sum Year1-10 & 224770.76 & 93751.25 & 210898.81 & 66915.77 \\
\hline Sum Year11-20 & 211588.20 & 175980.00 & 72925.23 & 59415.69 \\
\hline Sum Year21-30 & 211945.51 & 177027.50 & 28177.18 & 23087.16 \\
\hline Sum Year31-40 & 211945.50 & 177027.50 & 10863.52 & 8901.10 \\
\hline Sum Year41-50 & 211945.50 & 177027.50 & 4188.36 & 3431.76 \\
\hline Sum Year51-60 & 211945.50 & 177027.50 & 1614.79 & 1323.09 \\
\hline Sum Year61-70 & 211945.50 & 177027.50 & 622.57 & 510.11 \\
\hline Sum Year71-80 & 211945.50 & 177027.50 & 240.03 & 196.67 \\
\hline Grand Total & $\mathbf{1 7 0 8 0 3 1 . 9 7}$ & $\mathbf{1 3 3 1 8 9 6 . 2 5}$ & $\mathbf{3 2 9 5 3 0 . 5 0}$ & $\mathbf{1 6 3 7 8 1 . 3 5}$ \\
\hline
\end{tabular}

$B / C$ Ratio $(80$ Years $)=163781.35 / 329530.5=0.50$

This B/C Ratio shows that tea is still not profitable at farm level in Pakistan even after we extending our analysis to the productive life cycle of tea plant i.e. 80 years.

Table 6 is recalculated by incorporating the values of subsidy, which the farmers are getting and the sum of cost and revenue after adding subsidy for every ten years from Year-1 to Year80 are given in Table 7.

Table 7: Discounted Cost and Revenue of Tea Production after adding Subsidy (Sum of Every Ten Years)(Per Acre)

\begin{tabular}{|l|r|r|r|r|}
\hline & \multicolumn{1}{|l|}{ Costs } & $\begin{array}{l}\text { Revenues } \\
\text { after } \\
\text { Subsidy }\end{array}$ & $\begin{array}{l}\text { Discounted } \\
\text { Yearts }\end{array}$ & $\begin{array}{l}\text { Discounted } \\
\text { Revenues after } \\
\text { Subsidy }\end{array}$ \\
\hline Sum Year1-10 & 224770.75 & 192158.51 & 210898.81 & 162743.84 \\
\hline Sum Year11-20 & 211588.18 & 264940.08 & 72925.21 & 89717.70 \\
\hline Sum Year21-30 & 211945.50 & 266344.92 & 28177.17 & 34831.25 \\
\hline Sum Year31-40 & 211945.5 & 266344.92 & 10863.52 & 13428.96 \\
\hline Sum Year41-50 & 211945.5 & 266344.92 & 4188.36 & 5177.44 \\
\hline Sum Year51-60 & 211945.5 & 266344.92 & 1614.79 & 1996.13 \\
\hline Sum Year61-70 & 211945.5 & 266344.92 & 622.57 & 769.59 \\
\hline Sum Year71-80 & 211945.50 & 266344.92 & 240.03 & 296.71 \\
\hline Grand Total & $\mathbf{1 7 0 8 0 3 1 . 9 3}$ & $\mathbf{2 0 5 5 1 6 8 . 1 1}$ & $\mathbf{3 2 9 5 3 0 . 4 7}$ & $\mathbf{3 0 8 9 6 1 . 6 3}$ \\
\hline
\end{tabular}

Using the compounded and discounted figures of costs and revenues after adding subsidy in Table 7, the B/C ratio is again calculated for 80 years as follows.

$\mathrm{B} / \mathrm{C}$ Ratio $(80$ Years $)=308961.63 / 329530.47=0.94$

This $9.4 \mathrm{~B} / \mathrm{C}$ Ratio shows a slight increase from the previously calculated $\mathrm{B} / \mathrm{C}$ ratio i.e. 0.91 , indicating that tea is still showing the same no profit no loss situation at farm level in Pakistan even after adding the subsidy with revenues and extending analysis to 80 years.

\section{Conclusions And Recommendations}

The results based on our analysis show that although tea is not profitable at farm level, the farmers are still engaged in this technology because no feasible option is available apart from tea plantation to them in their small farms as most of the land presently under tea cultivation is sloppy and in the hilly areas; it's a laborintensive crop and mechanization rarely used in tea plantation; very few days throughout the year in tea plantation are labor intensive and the farmers can utilize the rest of the time in some other revenue-generating activities; all the farmers are getting subsidy in the form of nursery, fertilizer and cost incurred for picking of 
fresh leaves from tea garden; farmers are also getting interest free credit for the initial four years of tea plantation; and tea plantation is considered as a status symbol by most of the farmers in the target area.

Tea growers make an initial investment for 3-4 years without any returns and then wait up to year-28 to year-29 to reach breakeven point. Credit providing institutions should take note of this fact and make plans to help tea growers in this period of tea production.

Agriculture experts (Researchers and extension personnel) should pay attention to the need of reducing the breakeven period through efforts aiming at greater productivity of tea per unit area because presently there is a big difference in actual and potential production of tea in Pakistan at farm level.

Agriculture extension personnel should arrange special training to enhance labor productivity in picking fresh leaves per day from an actual average of $20-25 \mathrm{~kg} /$ day to potential average of $35 \mathrm{~kg} /$ day.

The government should take step to increase the present purchase price of Rs. $15 / \mathrm{kg}$ of fresh tea leaves to a level acceptable to both the tea farmers and government.

\section{References}

[1] National Tea Research Institute (NTRI). (1999). "Tea cultivation in Pakistan".Islambad, Pakistan Agricultural Research council (PARC).

[2] Food and Agriculture Organisation (FAO). (2006). "Agricultural production indices".www.fao.org; statistical databases.

[3] FAO (2005). "Tea Market Studies: Egypt, Islamic Republic of Iran, Pakistan and Turkey". Indonesia, Committee on Commodity Problems Intergovernmental Group on Tea, Sixteenth Session Bali.

[4] Hanif, M., D.S Ahmed, F. Ahmad and Nauman (2004). "Agricultural Perspective and Policy". Ministry of Food, Agriculture and Livestock Islamabad January 2004. pp.31.

[5] Bakhsh, K., S. Hussain, and A.G. Zulfiqar. (2006). "Economics of growing Date Palm in Punjab, Pakistan". International Journal of Agriculture and Biology, Vol. 8, No. 6.

[6] Hussain, G. A. (2006). "Estimating Cost and Revenue From Grapes Production in Parwan Province of Afghanistan: A Long-Run Analysis". Peshawar, Pakistan Department of Agricultural Economics Faculty of Rural Social Sciences Agricultural University

[7] Watkins, T. and V. Silicon (2007). "An Introduction to Cost Benefit Analysis". Department of Economics San José State University USA. http://www.sjsu.edu/faculty/watkins/cba.htm. 